\title{
GENERAL HILBERT'S AND HARDY'S INEQUALITIES
}

\author{
MARIO KRNIĆ AND JOSIP PEČARIĆ
}

Abstract. In this paper we make some further generalizations of well known Hilbert's inequality and its equivalent form in two dimensional case. We also derive some results on Hardy's inequality. Then we apply our general results to homogeneous functions. A reverses of Hilbert's inequality are also given in integral case. Many other results of this type in recent years, follows as a special case of our results.

Mathematics subject classification (2000): 26D15.

Key words and phrases: Inequalities, Hilbert's inequality, Hardy's inequality, Hölder's inequality, homogeneous function, kernel, reverse inequality, equivalent inequalities.

\section{REFERENCES}

[1] K. F. ANDERSEN, Weighted Inequalities for Stieltjes transformation and Hilberts double series, Proc. Royal Soc. Edinburgh, 86A (1980), 75-84

[2] I. BRNETIĆ AND J. PEČARIĆ, Generalisation of Hilbert's Integral Inequality, Mathematical Inequalities and Applications, 7 (2004), 199-205

[3] I. BRnETIĆ AND J. PEČARIĆ, Generalization of Hilbert-type Inequalities, Mathematical Inequalities and Applications, 7 (2004), 217-225

[4] A. ČIŽMEŠIJA AND J. PEČARIĆ, Some New Genaralisations of Inequalities of Hardy and Levin-CochranLee, Bull. Austral. Math. Soc., 63 (2001), 105-113

[5] A. ČIŽMEŠIJA AND J. PEČARIĆ, On Bicheng-Debnath's Generalisations of Hardy's Integral Inequality, Internat. J. Math. \& Math. Sci. 274 (2001), 237-250

[6] I. GAVREA, Some Remarks on Hardy-Hilbert's integral inequality, Mathematical Inequalities and Applications 53 (2002), 473-477.

[7] K. JiCHANG AND T. M. RASSIAS, Hilbert Integral Operator Inequalities, Mathematical Inequalities and Applications, 34 (2000), 497-510

[8] M. KRnIĆ AND J. PeČARIĆ, Hilbert's Inequalities and theirs Reversions, Publ. Math. Debrecen, (to appear)

[9] A. KuFner, Zur Hardischen Ungleichung, Seminar Analysis 1982/83, IMath, Berlin (1983), 1-18

[10] A. KufNer AND B. OpIC, Hardy-type Inequalities, Pitman Researchs Notes in Mathematics Series, 219, Longman Scientifics \& Tehnical, Harlow, 1990

[11] LJ. Marangunić And J. PeČARIĆ, Some remarks on Hilbert's Integral Inequality, Revue d'Analyse Numerique et de Theorie de l'Approximation, (to appear)

[12] LJ. MARANGUNić AND J. PEČARIĆ, On some Hilbert's type Inequalities, (submitted)

[13] LJ. MARANGUNIĆ AND J.PEČARIĆ, On some New Majorized Results on Hilbert's Integral Inequality, International Journal of Pure and Applied Mathematics, (to appear)

[14] D. S. MitrinoviĆ, J. E. PEČARIĆ AND A. M. FINK, Classical and New Inequalities in Analysis, Kluewer Acad. Publish. (1993), 99-133

[15] T. C. PEACHEY, Some integral inequalities related to Hilbert's, Journal of Inequalities in Pure and Applied Mathematics 4, 1 Art.19 (2003), 1-8.

[16] G. J. Sinnamon, Operators on Lebesgue Spaces with General Measures, Thesis, McMaster Univ., (1987), (Ch.3, Sec.2)

[17] B. YANG, On Hilbert's integral inequality, J. Math. Anal. Appl 220 (1998), 778-785. 
[18] B. Yang, Z. Zhuohua AND L. Debnath, On new generalizations of Hardy's Integral Inequality, J. Math. Anal. Appl. 217 (1998), 321-327

[19] B. YANG AND L. DeBNATH, Generalizations of Hardy's Integral Inequalities, Internat. J. Math. \& Math. Sci. 223 (1999), 535-542

[20] B. YANG, On a General Hardy-Hilbert's integral inequality, Chin. Ann: of Math. 21A (2000), 401-408.

[21] B. YANG, On New generalizations of Hilbert's inequality, J. Math. Anal. Appl 248 (2000), 29-40

[22] B. YANG, On an extension of Hardy-Hilbert's integral inequality, Chin. Ann: of Math. 23A 2 (2002).

[23] B. YANG AND T. M. RASSIAS, On the way of Weight Coefficents and Research for the Hilbert-type inequalities , Mathematical Inequalities and Applications 64 (2003), 625-658

[24] H. YONG, All-sided generalisation about Hardy-Hilbert's integral inequalities, Acta Mathematica Sinica 444 (2001), 691-626. 